\begin{tabular}{l|l|l} 
Jurnal Eksplorasi Akuntansi & ISSN : 2656-3649 (Online) \\
Vol. 2, No 4, Seri B, November 2020, Hal 3533-3552 & http://jea.ppj.unp.ac.id/index.php/jea/issue/view/30
\end{tabular}

\title{
PENGARUH AUDIT OPERASIONAL, PENGENDALIAN INTERNAL, DAN GOOD CLINICAL GOVERNANCE TERHADAP EFEKTIVITAS PELAYANAN KESEHATAN PASIEN BPJS DI RUMAH SAKIT
}

\author{
Winda Riyasari ${ }^{1}$, Fefri Indra Arza ${ }^{2}$ \\ ${ }^{1}$ Alumni Jurusan Akuntansi Fakultas Ekonomi Universitas Negeri Padang \\ ${ }^{2}$ Jurusan Akuntansi Fakultas Ekonomi Universitas Negeri Padang \\ *Korespondensi: windariyasari@gmail.com
}

\begin{abstract}
This study aims to prove that the effect of operational audits, good internal and clinical governance in hospitals has an effect on the health services of goverment of public health patients in hospitals. The sample selection in this research used purposive sampling method with various criteria according to the research objectives. The total sample used as the object of research in this study is the desire of 15 hospitals in Padang city with the category of government-owned or private hospitals. The data analysis technique used in this study was a questionnaire that was designed according to the variables used in this study. The results of this study can prove that the audit has a positive effect on the health of goverment of public health patients in the hospital. With the results of the sig value $0.001<0.05$, and the $t$-count value of 3.366> t-t table 1.992, it can be concluded that the hypothesis H1 is accepted. In addition, this study can also prove empirically that good clinical governance has a positive effect on the health of goverment of public health patients in the hospital with a sig value of $0.002<0.05$ with a value of t-count 3.162> t-t table 1.992. So it can be concluded that the hypothesis H3 is accepted, while the internal control variable has no effect on the influence of goverment of public health patient health services in the hospital. it can be concluded that the hypothesis $\mathrm{H} 2$ is rejected. Suggestions for further research are expected to increase the number of research samples and also the year of observation. Can also use other variables that are used to measure the effectiveness of BPJS patient health services in the hospital.
\end{abstract}

Keywords: Operational Audit, Government of Pubic Health,Effectivities of Public Health Service, Hospital, Internal Control, Patient

How to cite (APA $6^{\text {th }}$ style):

Riyasari, W. \& Arza, F. I. (2020). Pengaruh Audit Operasional, Pengendalian Internal, Dan Good Clinical Governance Terhadap Efektivitas Pelayanan Kesehatan Pasien BPJS Di Rumah Sakit. Jurnal Eksplorasi Akuntansi, 2(4), Seri B. 3533-3552.

\section{PENDAHULUAN}

Seiring berkembangnya zaman, membaiknya laju perekonomian serta derajat kesehatan masyarakat yang juga meningkat, berdampak terhadap kebutuhan akan pelayanan rumah sakit 
yang memiliki kualitas bagus. Kebijakan pemerintah tentang pendirian rumah sakit, poliklinik, dan puskesmas pun merambah ke berbagai daerah (Ella, 2015). Masyarakat tidak hanya menilai kualitas tenaga medis rumah sakit tempatnya berobat namun masyarakat juga akan menyoroti kualitas pelayanan yang diberikan oleh pihak rumah sakit yang bersangkutan.

Hal ini juga diungkapkan oleh Divianto (2012) bahwa bukan hanya sekedar kualitas tempat pelayanan saja yang menjadi sorotan masyarakat umum tetapi kualitas dari pelayanan yang menjadi prioritas utama yang dibutuhkan oleh masyarakat dalam memenuhi kebutuhan akan pelayanan pengobatan. Rumah sakit merupakan salah satu sarana kesehatan tempat menyelenggarakan upaya kesehatan dengan memberdayakan para sumber daya manusia yang terlatih dan terdidik dalam menghadapi dan menangani masalah medis untuk pemulihan dan pemeliharaan kesehatan yang baik (Siregar, 2004).

Upaya kesehatan yang diselenggarakan oleh pihak medis memiliki tujuan untuk mewujudkan derajat kesehatan yang optimal bagi masyarakat (Ella, 2015). Oleh karena pihak manajemen rumah sakit harus sangat mempertimbangkan program pelayanan baik dari segi program penanganan medis secara langsung (Direct Medical Care) maupun program pelayanan fasilitas yang akan diberikan kepada masyarakat karena manajemen sebagai penanggungjawab internal rumah sakit.

Penelitian terdahulu yang dilakukan oleh Sri (2013) mengemukakan bahwa pelayanan publik menjadi persoalan di semua negara. Permasalahan pelayanan menjadi persoalan yang patut diberikan perhatian terutama di negara-negara miskin maupun negara berkembang.Fenomena keluhan masyarakat yang tidak jarang didapatkan oleh pihak institusi publik dalam konteks ini adalah rumah sakit menunjukkan bahwa perlunya pihak rumah sakit sebagai tempat diselenggarakannya upaya kesehatan untuk memanfaatkan fungsi audit manajemen dalam mengevaluasi segala kegiatan yang dilakukan.

BPJS merupakan salah satu fasilitas pelayanan kesehatan yang didukung langsung oleh pemerintah adalah kegiatan kerjasama dengan program JKN/BPJS yang dibuat oleh pemerintah sesuai dengan "Undang-undang Nomor 40 tahun 2014" yang isinya adalah tentang SJSN atau Sistem Jaminan Sosial Nasional. BPJS atau Badan Penyelenggara Jaminan Sosial Kesehatan merupakan suatu badan khusus yang bertanggung jawab dalam menyelenggarakan jaminan kesehatan yang mana BPJS memiliki tujuan yang selaras dengan Organisasi Kesehatan Dunia dalam menjamin mutu kesehatan untuk seluruh penduduk (Syaputra, 2015).

Sedangkan Whistleblower adalah seseorang (pegawai/mantan pegawai dalam organisasi) yang melakukan tindakan pengungkapan/memberitahukan kepada publik atau kepada manajemen puncak tentang adanya dugaan tindakan illegal/tidak etis (Susmanschi, 2012). Whistleblowing terbagi dua yaitu Whistleblowing internal dan eksternal. Namun, karena kurangnya sosialisasi dari pemerintah mengenai procedural program baru BPJS ini kurang yang awalnya BPJS diharapkan bisa menjadi sarana untuk peningkatan derajat kesehatan bagi seluruh penduduk pada akhirnya menjadi menimbulkan masalah yang muncul karena keluhan dari masyarakat tentang susahnya prosedur BPJS tersebut.

Namun, terkadang kurang maksimalnya pelayanan kesehatan program BPJS tersebut juga disebabkan karena faktor kelalaian dari pihak rumah sakit. Sehingga, pihak rumah sakit sering mendapatkan komplain atau keluhan dari masyarakat karena merasapelayanan publik yang dilakukan pihak intern kurang memuaskan. Penelitian Ella dkk (2015) didukung oleh penelitain sebelumnya yang dilakukan oleh Cahyati (2012) yang menyatakan bahwa dengan mempertimbangkan semakin banyaknya kebutuhan akan pelayanan kesehatan ini, pihak manajemen rumah sakit perlu untuk mendorong efektivitas pelayanan kesehatan demi 
meningkatkan kualitas pelayanan kesehatan dengan memanfaatkan fungsi audit operasional dalam pengelolaan pelayanan kesehatan.

Agoes (2012) mengemukakan bahwa Management Audit, disebut juga Operational Audit adalah suatu pemeriksaan terhadap kegiatan operasi suatu perusahaan, termasuk kebijakan akuntansi dan kebijakan manajemen, untuk mengetahui apakah kegiatan operasi tersebut sudah dilakukan secara efektif dan efisien. Definisi efektif itu sendiri menurut Ratminto dan Atik Septi Winarsih (2009:179) dalam penelitian Ella dkk (2015) adalah tercapainya tujuan yang telah ditetapkan, baik itu dalam bentuk target masyarakat maupun dalam rangka pelaksanaan ketentuan peraturan perundang-undangan.

Pengendalian internal di dalam perusahaan juga merupakan salah satu faktor penting yang akan menentukan efektivitas pelayanan kesehatan selain audit operasional yang merupakan alat evaluasi seluruh kegiatan operasional yang ada didalam perusahaan. Pengendalian internal dibutuhkan sebagai alat pengatur seluruh kegiatan yang ada didalam perusahaan. Tingkat efektivitas dari seluruh kegiatan yang dilakukan oleh perusahaan tergantung pada kuat dan lemahnya sistem pengendalian internal (SPI) yang dirancang oleh pihak manajemen. Apabila pengendalian internalnya kuat maka kesalahan yang akan dilakukan dan akan mengurangi efektivitas kegiatan pelayanan kesehatan akan dapat diminimalisir.

Good Corporate Governance juga sangat diperlukan dalam struktur tatananorganisasi sebuah sektor publik (Ella dkk, 2015). Menurut PP Republik Indonesia No. 77 tahun 2015 tentang Pedoman Organisasi Rumah Sakit, pada pasal 2 dikatakan bahwa Pengaturan pedoman organisasi Rumah Sakit bertujuan untuk mewujudkan organisasi Rumah Sakit yang efektif, efisien, dan akuntabel dalam rangka mencapai visi dan misi Rumah Sakit sesuai tata kelola perusahaan yang baik (Good Corporate Governance) dan tata kelola klinis yang baik (Good Clinical Governance).

Untuk rumah sakit, tata kelola yang diberlakukan akan berbeda dengan organisasi yang tidak bergerak di bidang kesehatan, sehingga tata kelola rumah sakit yang baik dan berbasis medis bisa disebut dengan Good Clinical Governance. Berbeda dengan organisasi atau perusahaan yang tidak berbasis medis, Clinical governance yang baik dinilai tanggungjawab atau akuntabilitasnya berdasarkan kinerja klinis bukan kinerja yang lain karena ini berdasarkan setting rumah sakit (Ella dkk, 2015).

Clinical Governance merupakan suatu kerangka kerja organisasi yang akuntabel untukmeningkatkan kualitas layanan dan menerapkan standar tinggi layanan dengan menciptakan lingkungan yang kondusif untuk melakukan layanan klinis (NHS-UK Department of Health 1998) dalam (Ella dkk, 2015). Oleh karena itu dapat disimpulkan dari penjabaran diatas bahwa efektivitas pelayanan pasien BPJS akan sangat dipengaruhi dengan audit operasional sebagai bentuk dari pengimplementasian tujuan rumah sakit dalam meningkatkan derajat kesehatan masyarakat dan Good Clinical Governance sebagai pedoman tindakan pelayanan yang berbasis medis dalam pengimplementasian tujuan rumah sakit sebagai tempat penyelengaraan sarana kesehatan bagi seluruh masyarakat.

Penelitian ini mereplikasi dari peneliti sebelumnya yang dilakukan oleh Ella dkk (2015) yang mana penelitian tersebut menyatakan bahwa audit operasional dan tata kelola medis organisasi atau Good Clinical Governance memiliki pengaruh terhadap efektivitas pelayanan kesehatan baik dari segi pelayanan kesehatan program BPJS. Perbedaan dari penelitian sebelumnya yakni terletak pada objek dan lokasi penelitian. Penelitian ini dilakukan di Kota Padang, yang juga merupakan ibukota dari provinsi sumatera barat, dengan menggunakan sampel empat (4) rumah sakit yang berada di kawasan Kota Padang. Peneliti juga menambahkan 
satu variabel independen berupa pengendalian internal yang peneliti duga dapat mempengaruh tingkat efektivitas pelayanan pasien BPJS di rumah sakit.

Tujuan dari penelitian ini adalah untuk membuktikan dan memperoleh bukti empiris sejauhmana pengaruh dari audit operasional, pengendalian internal dan good clinical governance di rumah sakit terhadap efektivitas pelayanan pasien BPJS di rumah sakit. Maka dari itu peneliti tertarik untuk mengambil judul penelitian yakni: "Pengaruh Audit Operasional, Pengendalian Internal dan Good Clinical Governance Rumah Sakit Terhadap Efektivitas Pelayanan Pasien BPJS di Rumah Sakit (Studi Empiris Rumah Sakit di Kawasan Kota Padang)"

\section{REVIEW LITERATUR DAN HIPOTESIS \\ Teori Keagenan (Agency Theory)}

Teori keagenan atau agency theory menurut Meckling (1976) adalah hubungan antara manajer (agent) dengan pemilik (principal). Jika dikaitkan dalam organisasi pelayanan kesehatan seperti rumah sakit maka hal ini dapat dikaitkan antara hubungan pihak eksekutif, yang dalam hal ini pemerintah sebagai pembuat aturan maupun regulasi mengenai izin dan penyelenggaraan rumah sakit dengan pihak legislatif yang dalam hal ini adalah para pimpinan didalam sebuah rumah sakit itu sendiri.

Menurut Meisser et al (2006) teori keagenan dapat menimbulkan masalah yakni asimetri informasi dan konflik kepentingan, dimana ada salah satu pihak yang mendapatkan informasi lebih banyak dibandingkan pihak lainnya. Sebagai contoh dalam bidang pelayanan kesehatan yakni pada BPJS Kesehatan dimana masyarakat sebagai penerima manfaat dari BPJS Kesehatan yang dapat disebut sebagai agen memiliki lebih banyak informasi dibandingkan BPJS Kesehatan itu sendiri.

\section{Stewardship Theory (Teori Tata Laksana)}

Teori Stewardship adalah teori yang menggambarkan situasi dimana para manajer atau pimpinan sebuah organisasi tidaklah termotivasi oleh tujuan-tujuan individu tetapi lebih ditujukan pada sasaran hasil utama mereka untuk kepentingan organisasi.teori ini mempunyai dasar psikologi dan sosiologi yang telah dirancang dimana para pihak eksekutif sebagai steward termotivasi untuk bertindak sesuai keinginan principal, selain itu perilaku steward tidak akan meninggalkan organisasinya sebab steward berusaha mencapai target dan sasaran dari organisasi tersebut. Teori Stewardship dirancang bagi para peneliti untuk menguji situasi dimana para eksekutif atau pimpinan sebuah organisasi ataupun instansi sebagai pelayan untuk dapat bertindak dengan cara terbaik pada principalnya (Donaldson dan Davis, 1989, 1991).

\footnotetext{
Audit

Audit adalah hal yang tidak asing dalam dunia akuntansi. Hal ini karena audit merupakan salah satu ilmu dasar dari akuntansi yang hampir selalu dibutuhkan dilapangan. Untuk pengertian dari audit sendiri, ada beberapa pengertian yang bisa dijadikan acuan untuk memahaminya beserta jenis-jenis audit itu sendiri. Menurut PSAK, pengertian audit adalah suatu proses sistematik yang bertujuan untuk mengevaluasi bukti yang dikumpulkan atas pernyataan atau asersi mengenai berbagai aksi ekonomi, kejadian-kejadian dan melihat tingkat hubunganantara pernyataan atau asersi dengan kenyataan, serta mengomunikasikan hasilnya kepada yang berkepentingan.
} 


\section{Audit Operasional}

Menurut Guy (2003), audit operasional merupakan penelaahan atas bagian manapun dari prosedur dan metode operasi suatu organisasi untuk menilai efisiensi dan efektivitasnya. Audit operasional kadang-kadang disebut audit kinerja, audit manajemen, atau audit komprehensif. Informasi yang terukur dalam audit operasional adalah banyaknya pencatatan transaksi keuangan yang diproses dalam satu bulan, biaya yang dikeluarkannya dan kesalahan-kesalahan yang terjadi.

Bukan hanya efisiensi dan efektivitas saja yang dievaluasi oleh auditor internal namun kualitas kinerja sumber daya manusia (SDM) didalamnya ketika melaksanakan tanggung jawab penugasan juga akan menjadi evaluasi pihak independen (Ella, 2015). Output dari audit operasional adalah pendapat mengenai efisiensi, efektivitas, ekonomisasi suatu perusahaan beserta kinerja SDM dan dilengkapi dengan rekomendasi.

\section{Pengendalian Internal}

Pengendalian internal merupakan bagian yang sangat penting agar tujuan perusahaan dapat tercapai. Tanpa adanya pengendalian internal, tujuan perusahaan tidak dapat dicapai secara efektif dan efisien. Semakin besar perusahaan semakin penting pula arti dari pengendalian internal dalam perusahaan tersebut. Guna memperoleh pemahaman yang lebih luas mengenai pengendalian internal, maka penulis secara berurutan akan mengemukakan hal-hal yang berhubungan dengan pengendalian internal tersebut (Pratiwi, 2014:12).

\section{Good Clinical Governance}

Governance atau dalam bahasa indonesia artinya adalah tatakelola. Tata kelola merupakan sesuatu yang berkaitan dengan mekanisme untuk menjalankan fungsi pengarahan dan pengendalian pada suatu organisasi, entitas bahkan suatu sistem sesuai dengan tujuan dan harapan yang hendak dicapai oleh stakeholders (The Indonesian Institute forCorporate Governance (IICG), 2012). Tujuan tata kelola rumah sakit pada umumnya guna mempertahankan serta meningkatkan kualitas pelayanan kesehatan terhadap pasien dimana tata kelola ini dinilai akuntabel pada pelaksanaanya.

\section{Pengertian Rumah Sakit}

Undang-Undang Republik Indonesia Nomor 44 Tahun 2009Rumah sakit adalah institusi pelayanan kesehatan yang menyelenggarakan pelayanan kesehatan perorangan secara paripurna yang menyediakan pelayanan rawat inap, rawat jalan, dan gawat darurat. Menurut Penelitian Griffith 1987 dalam penelitian Rijadi 1997, Rumah Sakit adalah insitusi yang bertujuan untuk memberikan pelayanan kesehatan individual dengan menggunakan sumber daya secara efektif dan efisien guna kepentingan masyarakat.

\section{BPJS}

BPJS adalah badan usaha milik negara yang diberikan tugas khusus oleh pemerintah untuk menyelenggarakan jaminan pemeliharaan kesehatan untuk seluruh rakyat Indonesia, terutama untuk PNS (Pegawai Negeri Sipil), penerima pensiun PNS dan Polri atau TNI, Veteran, Perintis kemerdekaan; serta keluarganya dan badan usaha lainnya maupun rakyat biasa. Dalam hal ini setiap WNI (Warga Negara Indonesia)danWNA (Warga Negara Asing) yang sudah berdiam atau tinggal di Indonesia selama minimal 6 (enam) bulan wajib untuk menjadi anggota BPJS Kesehatan. 
Hal ini sesuai dengan ketentuan yang ada pada Pasal 14 UU BPJS. Setiap perusahaan wajib untuk mendaftarkan pekerjanya sebagai anggota BPJS Kesehatan. Peserta BPJS dibagi menjadi dua kategori yakni : Peserta BPJS Kesehatan penerima bantuan iuran dan Peserta BPJS Kesehatan non penerima bantuan iuran.

\section{Efektivitas Pelayanan Kesehatan}

Pengertian efektivitas secara umum menunjukan sampai seberapa jauh tercapainya suatu tujuan yang terlebih dahulu ditentukan. Efektivitas menurut Divianto (2012) menjelaskan bahwa efektivitas adalah suatu ukuran yang menyatakan seberapa jauh target ( kuantitas, kualitas, dan waktu) telah tercapai. Efektivitas pelayanan kesehatan pada rumah sakit mencakup berbagai aspek seperti kualitas jasa pelayanan, standar pelayanan, prinsip-prinsip dalam pelayanan publik.

\section{Penelitian Terdahulu}

Icah Cahyati, 2013, "Pengaruh audit operasional terhadap efektivitas pelayanan kesehatan rawat inap di rumah sakit". Hasil dari penelitian menemukan bahwa audit operasional memiliki pengaruh sebesar 53,7 \% dalam peningkatan efektivitas layanan kesehatan pada rumah sakit di daerah cibabat, sementara 46,3 \% dipengaruhi oleh faktor lainnya yang tidak dipakai didalam penelitian seperti stuktur organisasi, kedisiplinan dari seluruh anggota pegawai rumah sakit, serta sumber daya manusia yang dimiliki.

Risandra, Rejina 2014, "Peranan audit operasional terhadap efektivitas kinerja karyawan studi kasus pada PT. Indosat, Tbk, pada bagian data IT Center. Dengan menggunakan beberapa variabel penelitian diantaranya: Tindak lanjut audit, kualifikasi auditor, dan program audit. Dari hasil penelitian yang dilakukan menunjukkan bahwa audit operasional secara bersama-sama mempengaruhi kinerja karyawan, sedangkan variabel tindak lanjut audit berpengaruh secara parsial terhadap efektifitas kinerja karyawan.

Devianto, 2012, Peranan Audit Operasional Terhadap Efektivitas Pelayanan Kesehatan Rawat Inap di Rumah Sakit. Hasil Penelitian menyimpulkan bahwa Peranan Audit operasional pada Rumah Sakit Bunda Palembang mempunyai pengaruh terhadap efektivitas pelayanan kesehatan rawat inap pada rumah sakit. Anggit Puswitasari, 2013, "Pengaruh pengendalian internal dan komitmen organisasi dalam pencegahan fraud pengadaan barang (Studi lapangan pada lima rumah sakit di kota bandung). Dari hasil penelitian dapat disimpulkan bahwa pengendalian internal berpengaruh positif terhadap pencegahan fraud dalam pengadaan barang. Sedangkan komitmen organisasi berpengaruh signifikan positif terhadap pencegahan fraud, maka dengan adanya pengendalian internal yang bermutu maka tindakan fraud dapat dicegah dengan adanya kontrol yang ketat dari organisasi serta komitmen berkelanjutan untuk menciptakan budaya organisasi yang kondusif.

\section{Pengembangan Hipotesis}

\section{Audit Operasional dan Efektivitas Pelayanan Kesehatan Pasien BPJS}

Audit operasional merupakan sebuah tahapan evaluasi terhadap kegiatan operasional perusahaan untuk melihat tingkat efektivitas kegiatan operasional perusahaan (Agoes, 2012:11). Audit operasional memiliki peran penting dalam mencari cara untuk memperbaiki operasional perusahaan yang dinilai belum efektif (Dale L. Flesher dan Steward Siewert, 2001).

Divianto (2012) menemukan bahwa audit operasional berpengaruh positif terhadap efektivitas pelayanan kesehatan pasien rawat inap di rumah sakit. Penelitian ini sejalan dengan penelitian yang dilakukan oleh Ella (2015). Ia berpendapat bahwa audit operasional dapat 
meningkatkan efektivitas pelayanan kesehatan pasien JKN/BPJS di rumah sakit. Hal ini menjelaskan bahwa dengan diterapkannya fungsi audit operasional akan dapat meningkatkan efektivitas pelayanan kesehatan di rumah sakit. Berdasarkan penjelasan diatas, maka dapat ditarik hipotesis sebagai berikut.

$\mathbf{H}_{1}$ : Audit operasional berpengaruh positif terhadap pelayanan kesehatan pasien BPJS di rumah sakit

\section{Pengendalian Internal dan Efektivitas Pelayanan Kesehatan Pasien BPJS di Rumah Sakit}

Pengendalian internal memiliki lima komponen penting yaitu, lingkungan pengendalian, aktivitas pengendalian, penaksiran resiko, informasi dan komunikasi, serta pemantauan. Dengan adanya pemantauan dan aktivitas pengendalian oleh manajemen rumah sakit, maka akan meminimalisir kesalahan-kesalahan dalam pelaksanaan pelayanan kesehatan, yang dapat menyebabkan ketidakefektivan fungsi pelayanan kesehatan (Oktarnia, 2014).

Penelitian yang dilakukan oleh Marbu (2006), Usman (2013), Oktarnia (2014), dan Arvianita (2015) menyatakan bahwa pengendalian internal dapat meningkatkan kinerja karyawan yang akan berdampak pada tingkat efektivitas pelayanan yang diberikan oleh karyawan kepada masyarakat. Penelitian tersebut juga membuktikan bahwa di rumah sakit tingkat efektivitas pelayanan jaminan kesehatan BPJS juga sangat tergantung pada kuat lemahnya pengendalian internal. Maka dapat ditarik hipotesis sebagai berikut.

$\mathbf{H}_{2}$ : Pengendalian internal berpengaruh positif terhadap efektivitas pelayanan kesehatan pasien BPJS di rumah sakit

\section{Good Clinical Governance dan Efektivitas Pelayanan Kesehatan Pasien BPJS di Rumah Sakit}

Tata kelola organisasi yang berlaku di rumah sakit merupakan tata kelola berlandaskan medis yang disebut good clinical governance. Menurut NHS-UK Department of Health (1998) dalam Ella (2015) Clinical Governance yaitu suatu kerangka kerja organisasi yang akuntabel, untuk meningkatkan kualitas pelayanan klinis dan menciptakan lingkungan yang mendukung rumah sakit melakukan pelayanan klinis. Good Clinical Governance memiliki fungsi menjaga kegiatan operasional pelayanan kesehatan di rumah sakit tetap berjalan dengan baik.

Penelitian Bayu (2012), Jeles (2015), dan Ella (2015) membuktikan penerapan good clinical governance akan meningkatkan efektivitas pelayanan kesehatan.Penelitian tersebut menyatakan bahwa good clinical governance berpengaruh positif terhadap peningkatan efektivitas pelayanan kesehatan di rumah sakit termasuk pelayanan jaminan kesehatan BPJS. Tata kelola medis yang baik di rumah sakit juga akan mempengaruhi tingkat efektivitas pelayanan jaminan kesehatan BPJS. Dari penjelasan diatas maka dapat ditarik hipotesis penelitian sebagai berikut.

H3: Good clinical governance berpengaruh positif terhadap efektivitas pelayanan kesehatan pasien BPJS di rumah sakit

\section{METODE PENELITIAN}

Penelitian ini merupakan penelitian kausal komparatif dengan pendekatan kuantitatif dengan karakteristik masalah yang berupa hubungan sebab-akibat antara dua variabel atau lebih Arvianita (2015). Terdapat 4 variabel didalam penelitian ini, efektifitas pelayanan kesehatan pasien BPJS sebagai variabel dependen (variabel yang dipengaruhi), sedangkan ke tiga variabel lainnya, audit operasional, pengendalian internal, dan good clinical governance. Metode 
penelitian ini menggunakan metode deskriptif analisis, yaitu penelitian yang dilakukan dengan cara mengumpulkan dan menyajikan data yang akan disertai dengan analisis yang nantinya akan menjelaskan gambaran mengenai objek penelitian.

\section{Populasi dan Sampel}

Populasi yang digunakan dalam penelitian ini adalah 27 rumah sakit yang ada dikota padang yang terdiri dari rumah sakit milik pemerintah maupun rumah sakit swasta. Keseluruhan rumah sakit yang menjadi populasi penelitian juga harus memiliki pelayanan BPJS kesehatan agar sesuai dengan judul pada penelitian.

\section{Sampel}

Sampel merupakan bagian dari jumlah yang dimiliki oleh populasi dan memiliki karakteristik yang sudah ditetapkan oleh peneliti (Sugiyono, 2013:80). Sampel pada penelitian ini adalah pegawai dari rumah sakit milik pemerintah maupun rumah sakit swasta yang ada dikota padang dengan jabatan sebagai auditor internal. Pada penelitian ini penentuan sampel ditetapkan dengan teknik Purposive Sampling, yakni pengambilan sampel berdasarkan kriteria yang dipilih untuk memenuhi kebutuhan data penelitian.

Pengambilan sampel pada bagian auditor internal dilakukan agar dapat mengetahui pengendalian internal yang diterapkan pihak rumah sakit serta efektivias pelayanan pasien BPJS kesehatan yang telah diterapkan pihak rumah sakit. Hal ini dilakukan dikarenakan auditor internal mampu memberikan saran atau rekomendasi perbaikan kepada pihak manajemen untuk dapat melakukan perbaikan terhadap pelayanan yang diberikan selama ini kepada seluruh pasien atau pengunjung rumah sakit. Rumah sakit yang menjadi sampel penelitian berjumlah 15 (lima belas rumah sakit) hal ini dikarenakan ada beberapa rumah sakit dari populasi yang ada yang belum menjalankan program BPJS kesehatan selama tiga (3) tahun terakhir.

\section{Jenis, Sumber dan Teknik Pengumpulan Data}

Pada penelitian ini jenis data yang digunakan adalah data subjek (self report) berupa pandangan pihak auditor internal rumah sakit terhadap audit operasional yang dilakukan, pengendalian internal dan good clinical governance terhadap efektivitas pelayanan kesehatan yang telah diberikan. Hal ini digunakan untuk melihat sejauhmana para responden memahami isi dari pertanyaan maupun pernyataan yang diberikan.

Data yang digunakan pada penelitian ini adalah data primer. Data primer adalah data yang diperoleh peneliti secara langsung dari responden, atas data pribadi responden, data pandangan terhadap audit operasional, pengendalian internal, good clinical governance yang mempengaruhi efektivitas pelayanan kesehatan pasien BPJS kesehatan di rumah sakit. Peneliti juga melakukan survey secara langsung ke lapangan untuk melihat kondisi yang terjadi terkait dengan penelitian yang dilakukan.

Teknik yang digunakan oleh peneliti dalam pengumpulan data adalah kuesioner. Kuesioner disebarkan kepada sampel yang telah dipilih oleh peneliti yang diantarkan langsung ke alamat masing-masing rumah sakit umum milik pemerintah daerah maupun rumah sakit milik swasta yang menjadi objek penelitian.

\section{Instrumen Penelitian}

Penelitian ini menggunakan kuesioner untuk membantu penulis memperoleh hasil atas perumusan masalah. Variabel yang diteliti menggunakan pengukuran skala likert 1 sampai 
dengan 5. Untuk variabel audit operasional, good clinical governance dan efektivitas pelayanan kesehatan pasien BPJS. Instrumen penelitian yang digunakan diadopsi dari penelitian sebelumnya yang dilakukan oleh Ella Dwi Dkk (2015). Sedangkan untuk instrumen dari variabel Pengendalian Internal diadopsi dari penelitian Arvianita (2015).

\section{Metode Analisis Data}

\section{Uji Validitas dan Realibilitas}

Uji validitas dimaksud untuk menilai sejauh mana suatu alat ukur dapat dipakai sebagai alat untuk mengukur item-item pertanyaan/pernyataan kuisioner dalam penelitian. Suatu item valid jika pertanyaan/ pernyataan pada kuesioner mampu untuk mengungkapkan suatu yang akan diukur oleh kuesioner tersebut.

Teknik yang digunakan untuk mengukur validalitas pada penelitian ini yakni Product Moment dari Karl Pearson dengan ketentuan adalah jika ${ }^{r}{ }_{\text {hitung }}{ }^{r}{ }_{\text {tabel, }}$ maka skor butir pertanyaan/pernyataan kuesioner tersebut valid. Dan sebaliknya jika ${ }^{{ }}{ }^{>}{ }^{r}{ }{ }^{r}{ }_{\text {tabel, }}$ maka skor butir pertanyaan/pernyataan kuesioner tersebut dinyatakan tidak valid. Uji Reliabilitas merupakan serangkaian pengukuran atau serangkaian alat ukur yang memiliki konsistensi jika pengukuran yang dilakukan dengan alat ukur itu dilakukan secara berulang (Sugiono; 2005).

\section{Uji Asumsi Klasik}

Uji asumsi klasik bertujuan untuk melihat kelayakan model serta untuk mengetahui apakah terdapat pelanggaran asumsi klasik dalam model regresi berganda, karena model regresi yang baik adalah model yang lolos dari pengujian asumsi klasik. Uji asumsi klasik terdiri dari beberapa yakni Uji Multikolinearitas, Uji Heterokedastisitas, Uji Normalitas, Uji Koefisien Determina, Uji Regresi Berganda, Uji Autokorelasi, Uji F-simultan dan Uji T-test (Hipotesis).

\section{HASIL DAN PEMBAHASAN \\ Gambaran Umum Objek Penelitian}

Populasi dalam penelitian ini adalah seluruh audit internal rumah sakit di Kota Padang. Saat ini jumlah Jumlah Rumah Sakit Umum Pemerintah dan Swasta di Kota Padang adalah sebanyak 21 rumah sakit. Sampel yang digunakan dalam penelitian ini adalah dengan menggunakan metode purposive sampling dimana yang menjadi sampel yaitu audit internal rumah sakit di Kota Padang, masing-masing ada 5-10 auditor internalmaka setiap rumah sakit sampel disebar 5-10 kuisioner.

Peneliti melakukan pembagian kuesioner secara langsung turun kelapangan dan mendatangi setiap rumah sakit umum milik pemerintah maupun rumah sakit swasta yang ada di kota padang, kemudian kuesioner akan diambil kembali setelah satu bulan sejak kuesioner diberikan serta telah diisi secara lengkap. Hasil dari penyebaran dan pengembalian kuesioner dapat dilihat pada tabel 1 berikut :

Tabel 1

Tingkat pengembalian Kuesioner

\begin{tabular}{lcc}
\hline \multicolumn{1}{c}{ Keterangan } & Jumlah & Persentase \\
\hline Kuesioner yang didistribusikan & 100 & $100 \%$ \\
\hline Kuesioner yang kembali & 80 & $80 \%$ \\
\hline Kuesioner yang tidak dapat diolah & 20 & $20 \%$ \\
\hline Kuesionel yang diolah & 80 & $80 \%$ \\
\hline
\end{tabular}

Sumber : Data primer yang diolah, Tahun 2020 


\section{Demografi Responden}

Berdasarkan hasil kuesioner yang telah diisi oleh responden, diketahui karakteristik responden disajikan secara umum menurut kategori; Jenis kelamin, Usia dan Tingkat pendidikan. Karakteristik Responden Berdasarkan Jenis Kelamin Adapun untuk proporsi responden berdasarkan jenis kelamin dapat dilihat pada tabel 2 berikut ini:

Tabel 2

\begin{tabular}{cccc}
\multicolumn{4}{c}{ Karakteristik Responden Berdasarkan Jenis Kelamin } \\
\hline No & Jenis Kelamin & Frekuensi & Persentase (\%) \\
\hline 1 & Laki- laki & 36 & $45,0 \%$ \\
\hline 2 & Perempuan & 44 & $55,0 \%$ \\
\hline & Jumlah & 80 & $100 \%$ \\
\hline
\end{tabular}

Sumber : Data primer yang diolah, Tahun 2020

\section{Karakteristik Responden Berdasarkan Usia}

Berdasarkan kuesioner yang telah diisi secara lengkap dan dikumpulkan maka dapat diketahui kategori usia dari masing-masing responden. Tingkat usia merupakan salah satu faktor yang berkaitan erat dengan audit internal rumah sakit karena didasarkan oleh pengetahuan dan pengalaman yang dimiliki audit internal rumah sakit. Adapun kategori usia responden disajikan pada tabel 3 sebagai berikut:

Tabel 3

Karakteristik Responden Berdasarkan Usia

\begin{tabular}{cccc}
\hline No & Usia & Frekuensi & Persentase (\%) \\
\hline 1 & $20-30$ tahun & 16 & $20,0 \%$ \\
\hline 2 & $31-40$ tahun & 51 & $63,7 \%$ \\
\hline 3 & $41-50$ tahun & 13 & $16,3 \%$ \\
\hline & Jumlah & 80 & $100 \%$ \\
\hline
\end{tabular}

Sumber : Data primer yang diolah, Tahun 2020

\section{Karakteristik Responden Berdasarkan Tingkat Pendidikan}

Berdasarkan kuesioner yang telah diisi secara lengkap dan dikumpulkan maka dapat diketahui kategori tingkat penddikan dari masing-masing responden. Tingkat pendidikan menentukan posisi audit internal rumah sakit. Adapun kategori tingkat pendidikan responden disajikan pada tabel 4 sebagai berikut:

Tabel 4

Karakteristik Responden Berdasarkan Tingkat Pendidikan

\begin{tabular}{ccccc}
\hline No & & Tingkat Pendidikan & Frekuensi & Persentase (\%) \\
\hline 1. & D3 & & 32 & $40,0 \%$ \\
\hline 2. & S1 & & 48 & $60,0 \%$ \\
\hline & & Jumlah & 80 & $100 \%$ \\
\hline
\end{tabular}

Sumber : Data primer yang diolah, Tahun 2020 


\section{Statistik Deskriptif}

Dalam penelitian ini menggunakan tiga variabel independen yakni Audit Operasional, Pengendalian Internal dan Good Clinical Governance. Sedangkan variabel dependen dalam penelitian ini adalah Efektivitas pelayanan kesehatan pasien BPJS di rumah sakit. Gambaran dari masing-masing variabel tersebut dapat lihat pada tabel 5 sebagai berikut:

\section{Tabel 5}

Statistik Deskriptif

\begin{tabular}{lrrrrrrr}
\hline \multicolumn{7}{c}{ Descriptive Statistics } \\
\hline & $\mathrm{N}$ & $\begin{array}{c}\text { Minimu } \\
\mathrm{m}\end{array}$ & $\begin{array}{c}\text { Maximu } \\
\mathrm{m}\end{array}$ & \multicolumn{2}{c}{ Mean } & \multicolumn{2}{c}{ Std. Deviation } \\
\hline & Statistic & Statistic & Statistic & Statistic & Std. Error & Statistic \\
\hline Audit Operasional & 80 & 102 & 135 & 1.14 & 1.24 & 11.06594 \\
\hline Pengendalian Internal & 80 & 57 & 95 & 77.77 & 1.04 & 9.31852 \\
\hline $\begin{array}{l}\text { Good Clinical } \\
\text { Governance }\end{array}$ & 80 & 39 & 65 & 54.04 & .64 & 5.71129 \\
\hline $\begin{array}{l}\text { Efektivitas Pelayanan } \\
\text { Kesehatan Pasien BPJS }\end{array}$ & 80 & 72 & 90 & 78.89 & .98 & 8.74823 \\
\hline Valid N (listwise) & 80 & 70 & & & \\
\hline Sumber: Data primenn
\end{tabular}

Sumber: Data primer diolah, Tahun 2020

Dari tabel 5 diatas, dapat dijelaskan bahwa untuk variabel audit operasional terlihat bahwa nilai audit operasional paling rendah 102 sedangkan nilai audit operasional paling tinggi 135 . Secara keseluruhan rata-rata nilai audit operasional 1,14 dengan standar deviasi sebesar 11,066. Variabel pengendalian internal terlihat bahwa nilai pengendalian internal paling rendah 57 sedangkan nilai pengendalian internal paling tinggi 95. Secara keseluruhan rata-rata nilai pengendalian internal77,77dengan standar deviasi sebesar 9,318.

\section{Uji Validitas}

Validitas masing-masing item kuesioner dilihat dengan menggunakan nilai Corrected Item-Total Colleration, dengan melihat $r_{\text {hitung }}>r_{\text {tabel, }}$, maka dapat dikatakan valid. Dalam penelitian ini menggunakan 80 responden, maka $\mathrm{r}_{\text {tabel }}$ untuk $\mathrm{N}=80$ adalah 0.223 . Berikut hasil pengolahan data untuk uji validitas pada Tabel 6:

\section{Tabel 6}

\section{Hasil Nilai Corrected Item - Total Colleration Terkecil}

\begin{tabular}{lccc}
\hline \multicolumn{1}{c}{ Instrumen Variabel } & $\begin{array}{c}\text { Nilai Corrected Item } \text { - Total } \\
\text { Colleration Terkecil }\end{array}$ & $\begin{array}{c}\mathbf{r}_{\text {tabel }} \\
\text { Sig. } \mathbf{0 , 0 5}\end{array}$ & Keterangan \\
\hline Efektivitas pelayanan $(\mathrm{Y})$ & 0,989 & 0,223 & Valid \\
\hline Audit Operasional $\left(\mathrm{X}_{1}\right)$ & 0,639 & 0,223 & Valid \\
\hline Pengendalian Internal $\left(\mathrm{X}_{2}\right)$ & 0,956 & 0,23 & Valid \\
\hline Good Clinical Governance $\left(\mathrm{X}_{3}\right)$ & 0,990 & 0,223 & Valid \\
\hline
\end{tabular}

Sumber: Data primer diolah, Tahun 2020 
Berdasarkan perhitungan nilai Corrected Item-Total Colleration yang diambil dari nilai terkecil pada tabel 6 diatas, menunjukkan hasil bahwa nilai terkecil Corrected Item-Total Colleration dari masing-masing item variabel $\mathrm{X}_{1}, \mathrm{X}_{2}, \mathrm{X}_{3}$, dan $\mathrm{Y}$ berada diatas $\mathrm{r}_{\text {tabel. }}$. Oleh karena $\mathrm{r}$ hitung $>\mathrm{r}$ tabel maka butir pertanyaan tersebut dapat dikatakan valid. Jadi dapat disimpulkan bahwa seluruh item variabel $\mathrm{X}_{1}, \mathrm{X}_{2}, \mathrm{X}_{3}$, dan $\mathrm{Y}$ adalah valid.

\section{Uji Reliabilitas (Reliability Analysis)}

Uji Reliabilitas digunakan untuk mengukur tingkat konsistensi antara hasil pengamatan dengan instrumen atau alat ukur yang digunakan pada waktu yang berbeda. Teknik yang digunakan untuk mengukur reliabilitas penelitian yakni dengan menggunakan nilai koefisien dari cronbach alpha. Untuk uji reliabilitas dalam penelitian ini dapat dilihat pada tabel 7 sebagai berikut:

\section{Tabel 7}

Hasil Uji Reliabilitas

\begin{tabular}{lcc}
\hline \multicolumn{1}{c}{ Instrumen Variabel } & $\begin{array}{c}\text { Nilai Cronbach's } \\
\text { Alpha }\end{array}$ & Keterangan \\
\hline Efektivitas pelayanan $(\mathrm{Y})$ & 0,999 & Reliabel \\
\hline Audit Operasional $\left(\mathrm{X}_{1}\right)$ & 0,992 & Reliabel \\
\hline Pengendalian Internal $\left(\mathrm{X}_{2}\right)$ & 0,998 & Reliabel \\
\hline Good Clinical Governance $\left(\mathrm{X}_{3}\right)$ & 0,999 & Reliabel \\
\hline
\end{tabular}

Sumber: Data primer diolah, Tahun 2020

Dari data pada tabel 7 dapat diambil kesimpulan bahwa secara keseluruhan variabel dapat dikatakan reliabel, sehingga hasil dari pernyataan dari masing-masing responden konsisten. Untuk variabel sikap memiliki nilai cronbac'hs aplha sebesar 0,999 dengan kategori baik dan reliabel.

\section{Uji Normalitas}

Uji ini merupakan uji normalitas dengan berdasarkan pada koefisien keruncingan (kurtosis) dan koefisien kemiringan (skewness). Jika uji normalitas terpenuhi maka dapat dilakukan pengujian lanjutan dalam analisis regresi berganda. Uji normalitas merupakan bagian dari pengujian asumsi klasik yang menjadi salah satu prasyarat dalam penelitian ini. Banyak berbagai macam pengujian dalam pengujian normalitas. Uji ini dilakukan dengan membandingkan statistik Jarque-Bera (JB) dengan nilai $\mathrm{X}^{2}$ tabel. Adapun dalam penelitian ini uji normalitas dapat dilihat pada tabel 8 berikut ini:

\section{Tabel 8}

Uji Normalitas Skewness dan Kurtosis

\begin{tabular}{|c|c|c|c|c|c|}
\hline \multicolumn{6}{|c|}{ Jerque-Bera (Skewness) } \\
\hline & \multirow{2}{*}{$\frac{\mathrm{N}}{\text { Statistic }}$} & \multicolumn{2}{|c|}{ Skewness } & \multicolumn{2}{|c|}{ Kurtosis } \\
\hline & & Statistic & Std. Error & Statistic & Std. Error \\
\hline Standardized Residual & 80 & .665 & .269 & -.394 & .532 \\
\hline Valid N (listwise) & 80 & & & & \\
\hline
\end{tabular}

Sumber: Data primer diolah, Tahun 2020 
Dari data pada tabel 8 yang telah diperoleh dari program SPSS, maka dapat dicari nilai JerqueBera (JB), jika nilai JB $<\mathrm{X}^{2}$, maka nilai residual terstandarisasi dinyatakan berdistribusi secara normal.

\section{Uji Multikolinearitas}

Uji Multikolinearitas digunakan untuk melihat apakah ditemukan adanya korelasi antar Uji multikolonearitas bertujuan untuk menguji apakah model regresi yang ditemukan terdapat kolerasi antar variabel bebas.Untuk mengujinya, dilakukan dengan melihat nilai Variance Inflantions Factor (VIF). Jika nilai VIF $<10$ dan tolerance $>0,1$, maka variabel dapat dikatakan bebas multikolonearitas. Data uji multikolinearitas dalam penelitian ini dapat dilihat pada tabel 9 sebagai berikut:

\begin{tabular}{|c|c|c|c|}
\hline \multicolumn{4}{|c|}{$\begin{array}{c}\text { Tabel } 9 \\
\text { Hasil Uji Multikolinearitas } \\
\end{array}$} \\
\hline \multicolumn{4}{|c|}{ Coefficients $^{\mathrm{a}}$} \\
\hline & & \multicolumn{2}{|c|}{ Collinearity Statistics } \\
\hline \multicolumn{2}{|c|}{ Model } & Tolerance & VIF \\
\hline \multirow[t]{4}{*}{1} & (Constant) & & \\
\hline & Audit Operasional & .884 & 1.131 \\
\hline & Pengendalian Internal & .566 & 1.767 \\
\hline & Good Clinical Governance & .592 & 1.688 \\
\hline
\end{tabular}

Sumber: Data primer diolah, Tahun 2020

Berdasarkan hasil uji multikolinearitas pada tabel 4.13 diatas, diperoleh nilai tolerance untuk variabel audit operasional sebesar 0,884, variabel pengendalian internal sebesar 0,566 dan variabel good clinical governance sebesar 0,592. Sedangkan nilai VIF variabel audit operasional sebesar 1,131, variabel pengendalian internal sebesar 1,767, dan variabel good clinical governance sebesar 1,688. Dari nilai tolerance dan VIF seluruh variabel tersebut, didapatkan bahwa seluruh variabel independen memiliki nilai tolerance $>0,10$ serta memiliki nilai VIF $<10$. Dengan demikian, dapat dikatakan bahwa tidak ditemukan korelasi variabel-variabel bebas antara satu dengan yang lainnya, atau dapat disimpulkan tidak terjadi multikolinearitas

\section{Uji Heterokedastisitas}

Uji heterokedastisitas dalam penelitian ini dilakukan dengan menggunakan Software SPSS Versi 23. Uji heterokedastisitas digunakan untuk melihat apakah model regresi apakah terjadi ketidaksamaan variabel dari satu pengamatan ke pengamatan lainnya. Uji heterokedastisitas dapat menggunakan metode Uji glejser. Syarat pengambilan keputusan dalam uji heterokedastisitas adalah jika nilai sig lebih besar $>$ dari pada 0,05 sebaliknya apabila nilai sig lebih kecil < dari pada 0,05 maka dapat dikatakan data dalam penelitian mengalami gejala heterokedastisitas. Uji heterokedastisitas dalam penelitian ini pada tabel 10 sebagai berikut: 


\section{Tabel 10}

Hasil Uji Heterokedastisitas

\begin{tabular}{|c|c|c|c|c|c|c|}
\hline \multicolumn{7}{|c|}{ Coefficients $^{\mathbf{a}}$} \\
\hline \multirow{2}{*}{\multicolumn{2}{|c|}{ Model }} & \multicolumn{2}{|c|}{$\begin{array}{l}\text { Unstandardized } \\
\text { Coefficients }\end{array}$} & \multirow{2}{*}{$\begin{array}{c}\begin{array}{c}\text { Standardized } \\
\text { Coefficients }\end{array} \\
\text { Beta }\end{array}$} & \multirow[b]{2}{*}{$\mathrm{t}$} & \multirow[b]{2}{*}{ Sig. } \\
\hline & & $\mathrm{B}$ & Std. Error & & & \\
\hline 1 & (Constant) & 12.132 & 5.676 & & 2.137 & .036 \\
\hline & Audit Operasional & -.003 & .043 & -.009 & -.078 & .938 \\
\hline & Pengendalian Internal & .026 & .064 & .060 & .398 & .692 \\
\hline & $\begin{array}{l}\text { Good Clinical } \\
\text { Governance }\end{array}$ & -.138 & .103 & -.197 & -1.343 & .183 \\
\hline
\end{tabular}

Sumber: Data primer diolah, Tahun 2020

Berdasarkan hasil uji heterokedastisitas yang terdapat pada tabel 10 diatas, didapatkan nilai signifikansi dari variabel audit operasional sebesar 0,938 , nilai signifikansi variabel pengendalian internal sebesar 0,692, dan nilai signifikansi untuk variabel good clinical governance sebesar 0,183. Dari hasil tersebut, diketahui bahwa seluruh variabel dalam penelitian ini memiliki nilai signifikansi $>0,05$, yang berarti dalam model regresi ini dapat dikatakan bahwa tidak ada variabel yang signifikan dengan variabel absolute. Dengan demikian dapat disimpulkan model yang digunakan dalam penelitian ini terbebas dari heterokedastisitas.

\section{Analisis Data}

Berdasarkan dari data kuesioner yang telah disebar serta dikumpulkan, maka akan dilakukan analisis data untuk mendapatkan hasil dari penelitian. Teknik analisis data dalam penelitian ini akan menggunakan regresi berganda. Hasil dari analisis data regresi berganda dapat dijelaskan pada tabel 11 sebagai berikut:

\section{Tabel 11}

Hasil Uji Koefisien Regresi Berganda

\begin{tabular}{|c|c|c|c|c|c|}
\hline \multicolumn{6}{|c|}{ Coefficientsa } \\
\hline \multirow[b]{2}{*}{ Model } & \multicolumn{2}{|c|}{$\begin{array}{l}\text { Unstandardized } \\
\text { Coefficients }\end{array}$} & \multirow{2}{*}{$\begin{array}{c}\text { Standardized } \\
\text { Coefficients }\end{array}$} & \multirow[b]{2}{*}{$\mathrm{t}$} & \multirow[b]{2}{*}{ Sig. } \\
\hline & $\mathrm{B}$ & Std. Error & & & \\
\hline 1 (Constant) & 24.867 & 10.770 & & 2.309 & .024 \\
\hline Audit Operasional & .277 & .082 & .351 & 3.366 & .001 \\
\hline Pengendalian Internal & -.141 & .122 & -.150 & -1.155 & .252 \\
\hline $\begin{array}{l}\text { Good Clinical } \\
\text { Governance }\end{array}$ & .617 & .195 & .403 & 3.162 & .002 \\
\hline
\end{tabular}

Sumber: Data primer diolah, Tahun 2020

\section{Uji Koefisien Determinasi ( $R^{2}$ Square)}

Uji koefiesien determinasi digunakan untuk mengetahui kontribusi variabel bebas terhadap variabel terikat dengan melihat dari nilai Adjusted $R$ Square, dikarenakan penelitian ini menggunakan analisis regresi berganda dengan menggunakan variabel lebih dari satu variabel. Adjusted $R^{2}$ berarti $R^{2}$ sudah disesuaikan dengan derajat bebas dari masing-masing jumlah 
kuadrat yang tercakup didalam perhitungan Adjusted $R^{2}$. Nilai dari koefisien determinasi dalam penelitian ini dapat dilihat pada tabel 12 sebagai berikut:

Tabel 12

Hasil Uji Koefisien Determinasi $\left(\mathbf{R}^{2}\right)$

\begin{tabular}{lcccr}
\hline \multicolumn{5}{c}{ Model Summary } \\
\hline Model & $\mathrm{R}$ & R Square & $\begin{array}{c}\text { Adjusted R } \\
\text { Square }\end{array}$ & Std. Error of the Estimate \\
\hline 1 & $.520^{\mathrm{a}}$ & .270 & .241 & 7.61957 \\
\hline $\begin{array}{l}\text { a. Predictors: (Constant), Good Clinical Governance, Audit Operasional, Pengendalian } \\
\text { Internal }\end{array}$
\end{tabular}

Sumber: Data primer diolah, Tahun 2020

Berdasarkan hasil uji koefisien determinasi pada tabel 12 diatas, diketahui bahwa nilai Adjust $R$ Square adalah sebesar 0,241 atau sama dengan 24,1\%. Hal ini menjelaskan bahwa variabel audit operasional, pengendalian internal dan good clinical governance memiliki kontribusi dalam menerangkan variabel dependen yaitu sebesar 24,1\%. Sedangkan sisanya yaitu sebesar 75,9\% dipengaruhi oleh variabel lain yang tidak terdeteksi dalam penelitian ini.

\section{Uji F (F-Simultan)}

Uji F dilakukan untuk melihat pengaruh secara bersama-sama antara variabel independen dengan variabel dependen. Kriteria pengambilan keputusan dalam Uji F menurut ghozali (2007) adalah sebagai berikut: Jika nilai nilai signifikansi lebih kecil < daripada 0,05 maka dapat dikatakan Ha diterima, dengan kata lain, seluruh variabel independen secara bersama-sama berpengaruh signifikan terhadap variabel dependen.

Uji $F$ juga dapat dilakukan dengan membandingkan antara $F_{\text {hitung }}$ dengan $F_{\text {tabel. }}$ Dimana jika $F_{\text {hitung }}>F_{\text {tabel }}$ maka terdapat pengaruh secara bersama-sama antara variabel independen dengan variabel dependen. Sebaliknya apabila nilai $\mathrm{F}_{\text {hitung }}<\mathrm{F}_{\text {tabel }}$ maka dapat disimpulkan tidak terdapat pengaruh secara bersama-sama antara variabel independen dengan variabel dependen.Uji $\mathrm{F}$ dalam penelitian ini dapat dilihat pada tabel 13 sebagai berikut:

Tabel 13

Hasil Uji F-Simultan

\begin{tabular}{llrrrrr}
\hline \multicolumn{7}{c}{ ANOVA $^{\mathbf{b}}$} \\
\hline Model & Sum of Squares & Df & Mean Square & F & Sig. \\
\hline \multirow{2}{*}{1} & 1633.593 & 3 & 544.531 & 9.379 & $.000^{\mathbf{a}}$ \\
\cline { 2 - 7 } & Regression & 4412.395 & 76 & 58.058 & & \\
\cline { 2 - 7 } & Residual & 6045.988 & 79 & & & \\
\hline
\end{tabular}

Sumber: Data primer diolah, Tahun 2020

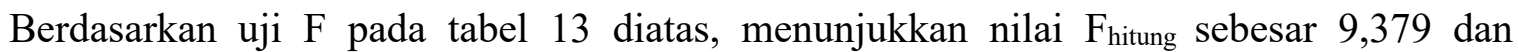
signifikan pada nilai signifikan 0,000 . Nilai $F_{\text {hitung }}>F_{\text {tabel yaitu }} 9,379>2,72$, dan nilai signifikansi $0,000<0,05$, maka dapat dipastikan bahwa model regresi dalam penelitian ini dapat digunakan dalam memprediksi pengaruh variabel independen terhadap variabel dependen dalam penelitian ini. Dengan demikian, dapat disimpulkan bahwa audit operasional, pengendalian internal dan 
good clinical governance secara bersama-sama atau secara simultan berpengaruh signifikan terhadap efektivitas pelayanan kesehatan BPJS.

\section{Uji Hipotesis (T-test)}

Uji hipotesis digunakan untuk mengetahui secara masing-masing pengaruh dari variabel independen terhadap variabel dependen.Uji hipotesis dapat dilakukan dengan melihat hasil dari olah data secara SPSS. Apabila nilai sig lebih kecil $<$ daripada 0,05 atau nilai $t_{\text {hitung }}>t_{\text {tabel }}$ maka dapat dikatakan terdapat pengaruh variabel $\mathrm{X}$ terhadap variabel Y. Sebaliknya apabila nilai sig lebih besar $>$ daripada 0,05 atau nilai $t_{\text {hitung }}<t_{\text {tabel }}$ maka dapat dikatakan tidak terdapat pengaruh antara variabel $\mathrm{X}$ terhadap variabel Y. Uji t dalam penelitian ini dapat dijabarkan sebagai berikut:

\section{Pengujian Hipotesis 1 (Satu)}

Nilai $t$ hitung untuk variabel audit operasional $\left(\mathrm{X}_{1}\right)$ adalah 3,366 dan nilai signifikan 0,001. Sehingga dapat diketahui bahwa $\mathrm{t}$ hitung $>\mathrm{t}$ tabel yakni 3,366>1,992 dan nilai signifikansi $0,001<$ 0,05 . Nilai koefisien $\beta$ dari variabel $X_{1}$ bernilai positif yaitu 0,277 . Hal ini menunjukkan dan membuktikan bahwa variabel audit operasional $\left(\mathrm{X}_{1}\right)$ berpengaruh positif dan signifikan terhadap efektivitas pelayanan kesehatan pasien BPJS. Maka dapat dikatakan

\section{Hipotesis $\mathbf{H}_{1}$ Diterima.}

\section{Pengujian Hipotesis 2 (dua)}

Nilai thitung untuk variabel pengendalian internal $\left(\mathrm{X}_{2}\right)$ adalah $-1,155$ dan nilai signifikan 0,252. Sehingga dapat diketahui bahwa $\mathrm{t}_{\text {hitung }}<\mathrm{t}$ tabelyakni $-1,155<1,992$ dan nilai signifikansi 0,252> 0,05 . Nilai koefisien $\beta$ dari variabel $X_{2}$ bernilai negatif yaitu 0,141 . Hal ini menunjukkan dan membuktikan bahwa variabel pengendalian internal $\left(\mathrm{X}_{2}\right)$ berpengaruh tidak signifikan terhadap efektivitas pelayanan kesehatan pasien BPJS. Maka dapat dikatakan Hipotesis $\mathbf{H}_{2}$ Ditolak

\section{Pengujian Hipotesis 3 (tiga)}

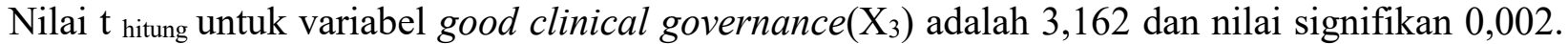
Sehingga dapat diketahui bahwa thitung $>t_{\text {tabel }}$ yakni 3,162 >1,992 dan nilai signifikansi 0,002< 0,05 . Nilai koefisien $\beta$ dari variabel $X_{3}$ bernilai positif yaitu 0,617 . Hal ini menunjukkan dan membuktikan bahwa variabel good clinical governance $\left(\mathrm{X}_{3}\right)$ berpengaruh positif dan signifikan terhadap efektivitas pelayanan kesehatan pasien BPJS. Maka dapat dikatakan Hipotesis $\mathbf{H}_{3}$ Diterima.

\section{PEMBAHASAN}

\section{Pengaruh Audit Operasional Terhadap Efektivitas Pelayanan Kesehatan Pasien BPJS di Rumah Sakit}

Berdasarkan hasil pengujian hipotesis pertama, dengan menggunakan model regresi linier berganda menunjukkan bahwa audit operasional berpengaruh positif dan signifikan terhadap efektivitas pelayanan kesehatan pasein BPJS di rumah sakit. Berdasarkan hasil pengujian yang telah dilakukan diperoleh nilai koefisien regresi audit operasional sebesar 0,277 artinya jika audit operasional naik sebesar satu satuan, maka efektivitas pelayanan kesehatan pasien BPJS di rumah sakit akan naik sebesar 0,277 untuk setiap satuannya, dengan asumsi variabel lain tidak mengalami perubahan atau konstan. Hal ini juga dibuktikan dengan hasil penelitian yang menyatakan bahwa nilai $t_{\text {hitung sebesar } 3,366>} t_{\text {tabel }}$ sebesar 1,992 dengan nilai signifikan 0,001< 
$\alpha=0,05$ artinya Ho ditolak Ha diterima. Artinya audit operasional berpengaruh positif dan signifikan terhadap efektivitas pelayanan kesehatan pasien BPJS di rumah sakit.

Hasil penelitian ini sejalan dengan hasil penelitian yang dilakukan oleh Divianto (2012) menemukan bahwa audit operasional berpengaruh positif terhadap efektivitas pelayanan kesehatan pasien rawat inap di rumah sakit. Penelitian ini juga sejalan dengan penelitian yang dilakukan oleh Ella (2015) peneliti berpendapat bahwa audit operasional dapat meningkatkan efektivitas pelayanan kesehatan pasien JKN/BPJS di rumah sakit.

Audit operasional merupakan sebuah tahapan evaluasi terhadap kegiatan operasional perusahaan untuk melihat tingkat efektivitas kegiatan operasional perusahaan (Agoes, 2012:11). Audit operasional memiliki peran penting dalam mencari cara untuk memperbaiki operasional perusahaan yang dinilai belum efektif (Dale L. Flesher dan Steward Siewert, 2001). Audit operasional akan membantu auditor menemukan bukti yang akan digunakan sebagai dasar pemberian rekomendasi perbaikan kepada indepemden perusahaan.Rekomendasi tersebut merupakan output audit operasional untuk meningkatkan efektivitas operasional perusahaan (Tunggal, 2000:5).

\section{Pengaruh Pengendalian Internal Terhadap Efektivitas Pelayanan Kesehatan Pasein BPJS di Rumah Sakit}

Berdasarkan hasil pengujian hipotesis kedua, dengan menggunakan model regresi linier berganda menunjukkan bahwa pengendalian internal berpengaruh negatif dan tidak signifikan terhadap efektivitas pelayanan kesehatan BPJS. Berdasarkan hasil pengujian yang telah dilakukan diperoleh nilai koefisien regresi audit operasionalsebesar $-0,141$. Hal ini juga dibuktikan dengan hasil penelitian yang menyatakan bahwa nilai $t_{\text {hitung }}$ sebesar $-1,155<t_{\text {tabel }}$ sebesar 1,992 dengan nilai signifikan $0,252>\alpha=0,05$ artinya $\mathrm{H}_{a}$ ditolak $\mathrm{H}_{0}$ diterima. Artinya pengendalian internal berpengaruh negatif dan tidak signifikan terhadap efektivitas pelayanan kesehatan pasien BPJS di rumah sakit.

Hasil penelitian ini tidak sejalan dengan hasil penelitian yang dilakukan oleh Marbu (2006), Usman (2013), Oktarnia (2014), dan Arvianita (2015) menyatakan bahwa pengendalian internal dapat meningkatkan kinerja karyawan yang akan berdampak pada tingkat efektivitas pelayanan yang diberikan oleh karyawan kepada masyarakat. Penelitian tersebut juga membuktikan bahwa di rumah sakit tingkat efektivitas pelayanan jaminan kesehatan BPJS juga sangat tergantung pada kuat lemahnya pengendalian internal.

Hasil penelitian ini juga tidak sejalan dengan pernyataan (Oktarnia, 2014) menyatakan dengan adanya pemantauan dan aktivitas pengendalian oleh manajemen rumah sakit, maka akan meminimalisir kesalahan-kesalahan dalam pelaksanaan pelayanan kesehatan, yang dapat menyebabkan ketidakefektivan fungsi pelayanan kesehatan. Semakin kuat sistem pengendalian internal yang dijalankan oleh pihak rumah sakit maka akan semakin tinggi tingkat efektivitas pelayanan kesehatan yang dijalankan.

\section{Pengaruh Pengaruh Good Clinical Governance Terhadap Efektivitas Pelayanan Kesehatan Pasein BPJS di Rumah Sakit}

Berdasarkan hasil pengujian hipotesis ketiga, dengan menggunakan model regresi linier berganda menunjukkan bahwa good clinical governance berpengaruh positif dan signifikan terhadap efektivitas pelayanan kesehatan pasien BPJS di rumah sakit. Berdasarkan hasil pengujian yang telah dilakukan diperoleh nilai koefisien regresi good clinical governance sebesar 0,617 artinya jika good clinical governance naik sebesar satu satuan, maka efektivitas 
pelayanan kesehatan pasien BPJS di rumah sakit akan naik sebesar 0,617 untuk setiap satuannya, dengan asumsi variabel lain tidak mengalami perubahan atau konstan. Hal ini juga dibuktikan dengan hasil penelitian yang menyatakan bahwa nilai $t_{\text {hitung }}$ sebesar 3,162> $t_{\text {tabel }}$ sebesar 1,992 dengan nilai signifikan $0,002<\alpha=0,05$ artinya Ho ditolak Ha diterima. Artinya good clinical governance berpengaruh positif dan signifikan terhadap efektivitas pelayanan kesehatan pasien BPJS di rumah sakit.

Hasil penelitian ini sejalan dengan hasil penelitian yang dilakukan oleh Bayu (2012), Jeles (2015), dan Ella (2015) membuktikan penerapan good clinical governance akan meningkatkan efektivitas pelayanan kesehatan.Penelitian tersebut menyatakan bahwa good clinical governance berpengaruh positif terhadap peningkatan efektivitas pelayanan kesehatan di rumah sakit termasuk pelayanan jaminan kesehatan BPJS. Tata kelola medis yang baik di rumah sakit juga akan mempengaruhi tingkat efektivitas pelayanan jaminan kesehatan BPJS.

Semakin baik dan professional penerapan good clinical governance maka akan semakin tinggi tingkat efektivitas pelayanan kesehatan terhadap masyarakat yang dapat tercapai (Bayu, 2012).Tata kelola rumah sakit tentu berbeda dengan perusahaan-perusahaan pada umumnya. Good Clinical Governance merupakan tata kelola rumah sakit yang sesuai dengan standar klinis yang telah ditetapkan. Menurut Penny (2003) dalam Rahmawati (2017) istilah Clinical Governance yang pertama kali digunakan oleh WHO pada tahun 1983, untuk membingkai suatu perawatan kesehatan yang berkualitas tinggi pada empat dimensi, yaitu kinerja yang profesional, alokasi sumber daya, manajemen risiko dan kepuasan pasien.

\section{KESIMPULAN}

Berdasarkan hasil penelitian mengenai pengaruh audit operasional, pengendalian internal dan good clinical governance rumah sakit terhadap efektivitas pelayanan kesehatan pasien BPJS di rumah sakit, dapat diambil kesimpulan sebagai berikut:

Tingkat capaian responden pada variabel sikap sangat tinggi serta dapat menggambarkan bahwa responden memahami dari setiap item pernyataan yang diberikan. Dari hasil penelitian untuk Audit operasional berpengaruh signifikan positif terhadap efektivitas pelayanan kesehatan pasien BPJS di rumah sakit. Pengendalian internal berpengaruh tidak signifikan terhadap efektivitas pelayanan kesehatan pasien BPJS di rumah sakit. good clinical governance berpengaruh signifikan positif terhadap efektivitas pelayanan kesehatan pasien BPJS di rumah sakit.

\section{SARAN}

Berdasarkan kesimpulan dan keterbatasan penelitian ini, berikut adalah saran yang bisa penulis sampaikan yaitu untuk meningkatkan efektivitas pelayanan kesehatan pasien BPJS rumah sakit di kota padang hendaknya pihak manajemen rumah sakit menambahkan alat medis yang baik sehingga pelayanan yang diberikan menjadi lebih efektif. Rumah sakit pasien BPJS di kota padang perlu memiliki staf satuan pengawas internal yang telah bersertifikat kualifikasi auditor internal untuk menjalankan kegiatan audit operasional.

Dengan demikian diharapkan dapat tercipta efektivitas pelayanan kesehatan pasien pada rumah Sakit yang baik. Sistem informasi akuntansi dan informasi manajemen yang dimiliki oleh rumah sakit untuk pelayanan pasien BPJS di kota padang hendaknya dikembangkan lagi untuk meningkatkan pengendalian internal pada rumah sakit, sehingga diharapkan dapat meningkatkan efektivitas pelayanan kesehatan pasien BPJS pada rumah Sakit. 
Penelitian selanjutnya diharapkan dapat menggunakan variabel lain yang belum ada dalam penelitian ini yang juga dapat mempengaruhi efektivitas pelayanan kesehatan pasien BPJS di rumah sakit serta dapat menggunakan indikator lain dalam pengukuran yang digunakan dalam penelitian. Penelitian selanjutnya juga dapat menggunakan teknik analisis yang berbeda seperti menggunakan teknik wawancara maupun trianggulasi data untuk melihat pengaruh antar variabel

\section{DAFTAR PUSTAKA}

Agoes, Sukrisno and Jan Hoesada. 2012. Bunga Rampai Auditing. Jakarta Selatan: Salemba Empat.

Agoes, Sukrisno. 2004. Auditing (Pemeriksaan Akuntan) oleh Kantor Akuntan Publik.Jakarta: Fakultas Ekonomi. 2004.

Al-Qurthubi, Imam. 2008. Tafsir Al-Qurthubi bagian 5(Terjemah Al-Jami' Li Ahkami Al-Qura, cet 1. Jakarta: Pustaka Azzam.

Amin, Widaja Tunggal. 2008. Audit Manajemen. Jakarta: Rineka Cipta.

Arens, A. Alvin and James K. Loebbecke. 1998. Auditing Suatu Pendekatan Terpadu.Jakarta: Erlangga.

Arvianita. 2015. Pengaruh Audit Operasional Dan Pengendalian InternalTerhadap Efektivitas Pelayanan Kesehatan Pada Rumah Sakit (Studi Kasus Pada Rumah Sakit Umum Queen Latifa Yogyakarta), Skripsi, dipublikasikan, Yogyakarta, UNY.

Bayangkara, IBK. 2008. Audit Manajemen: Prosedur dan Implementasi. Jakarta:Salemba Empat. Cahyati, Icah. 2013. Pengaruh Audit Operasional terhadap Efektivitas Pelayanan Kesehatan Rawat Inap di Rumah sakit (Studi Kasus RSUD Cibabat Cimah. Skripsi. Universitas Pasundan Bandung.

Divianto. 2012. Peranan Audit Operasional terhadap Efektivitas Pelayanan Kesehatan di Rumah sakit Bunda Palembang. Jurnal Ekonomi dan Informasi Akuntansi.

Depkes. 2009. Upaya Pelayanan Kesehatan, www.depkes.go.id.

Ella, dkk. 2015, Pengaruh Aduit Operasional dan Good Clinical Governanceterhadap Efektifitas Pelayanan Kesehatan JKN/BPJS, Bandung.

Fitrawansyah. Fraud dan Auditing. Jakarta: Mitra Wacana Media. 2013. Ghozali,Imam. Aplikasi Analisis Multivariate dengan program SPSS. Semarang:Universitas Diponogoro. 2005.

Gultom, Donna Adelina. 2014. Peranan Audit Operasional terhadap Peningkatan Mutu Pelayanan Kesehatan Rawat Inap di Rumah Sakit Umum Makasar. Skripsi. Universitas Hasanuddin.

Ikhsan, Arfan dkk. 2015. Auditing Pemeriksaan Akuntansi. Medan: Perdana Publishing.

Rahmawati. 2017. Pengaruh Audit Operasional, Pengendalian Internal, Good Clinical Governance, Etika Bisnis Lembaga Rumah Sakit Terhadap Efektivitas Pelayanan Kesehatan Pasien BPJS di Rumah Sakit (Studi Empiris Pada Rumah Sakit di Tulungangung), Skripsi, dipublikasikan, Yogyakarta, UMY). Skripsi. Dipublikasikan. Yogyakarta.UMY.

Ratmino dan Winarsih, Atik Septi. 2010. Manajemen Pelayanan, Yogyakarta :Pustaka Pelajar. Sugiyono. 2007. Metode Penelitian Bisnis (Pendekatan Kuantitatif, Kualitatif, dan R\&D), Alfabeta, Bandung.

Syaputra Diman. 2015. Hubungan Mutu Pelayanan Bpjs Kesehatan DenganKepuasan Pasien Di Instalasi Rawat Inap Kelas II Rumah Sakit Umum Daerah Sekayu, Musi. 
The Indonesian Institute for Corporate Governance (IICG). 2012. Good Corporate Governance $(G C C)$ pada Perspektif 4. Organisasi Pembelajar. Jakarta.

Utami, R. D. T., \& Titisari, K. H. 2017. Analisis Efektivitas Sistem Pengendalian Intern Persediaan Obat di Rumah Sakit Umum Kasih Ibu Surakarta.

Zulkarnain, Usman. 2013. Pengaruh Sistem Pengendalian Intern terhadap Kinerja Perusahaan (Studi Kasus pada PT MNC Sky Vision Cabang Gorontalo. Skripsi. Gorontalo: Universitas Negeri Gorontalo.

,2015.Peraturan Pemerintah Republik Indonesia Nomor 77 Tahun 2015 tentang Pedoman Organisasi Rumah Sakit.

2015. Peraturan Mentri Keuangan Republik Indonesia Nomor 92/PMK.05 Tahun 2011 tentang Badan LayananUmum.

,2016. Peraturan Presiden Nomor 19 Tahun 2016 tentang Jaminan Kesehatan 